\title{
DEVELOPMENT OF A CULTURED MILK BEVERAGE USING CHEDDER CHEES WHEY
}

\author{
I.W.P.Senarathna, ${ }^{1}$ R.M.A.S.Bandara, ${ }^{1}$.D.Wickramanayaka, ${ }^{1}$ E.U.Udayathilaka, ${ }^{2}$ and \\ A.W.Wijeratne ${ }^{3}$
}

\begin{abstract}
Presently there is a growing interest in utilization of whey by products. The study was carried out to develop a cultured milk beverage using Cheddar cheese whey. Used ingredients were Cheddar cheese whey, Mango pulp, Sugar, Full cream milk powder and yoghurt culture (DVS) and the role of each ingredient in the processing of the product was examined. Shelf life of most sensory scored sample was determined by evaluating chemical and microbial properties. According to the two factor factorial model 9 samples were obtained by mixing different levels of ingredients. A sensory evaluation was carried out to detect the appropriate levels of ingredients in the final product. Data were collected from 9 samples and were analyzed by using the Friedman test of the Minitab 15 software. Treatment with $1 L$ of whey, $100 \mathrm{ml}$ of Mango pulp, $180 \mathrm{~g}$ of sugar and $40 \mathrm{~g}$ of milk powder exhibited the highest overall acceptability with 11 days of shelf life. There was no treatment effect on viscosity.
\end{abstract}

Key Words: Whey, Sensory Evaluation, Friedman Test, Shelf life evaluation

\section{INTRODUCTION}

Normally all cheese are made from milk, but different manufacturing and aging processes are used to produce the range of cheese available today. Milk solids are selectively concentrated and preserved in the form of a palatable food, during cheese manufacture. Concentration of milk solids is initiated by the formation of a curd using culture and heat treatments. Once the curd formed, further acidification and heating is used to enhance the curding or formation of Calcium casienate configure. Modification of this basic process through accident or necessity, through centuries of cheese making, has led to the development of the several hundred of cheese varieties which now exist world wide.

Whey is the basic by-product of cheese manufacturing. Although there are variety types of cheese, all cheeses have to undergo the same basic processes. Finally, the cheese curd is braked up, separating a rich cloudy liquid from the solid pebblelike curds. This liquid cloudy water is known as whey. Whey has been known for decades as a product of high nutritional value. Since whey contains variable nutrients including $20 \%$ of the proteins and most of the lactose, minerals and water soluble vitamins it is now considered as a source of valuable constituent rater than a waste product. Today, the development of markets using whey products and fractions of whey as ingredients in foodstuffs for human and animal consumption have transformed the previously troublesome by-product whey into a valuable product for the dairy and cheese-making industries.

Whey contains a low fat percentage. So it can be used as an ingredient to produce low fat food products and this is very

\footnotetext{
${ }^{1}$ Department of Livestock Production, Faculty of A gricultural Sciences, Sabaragamuwa University of Sri Lanka

${ }^{2}$ MILCO (Pvt) Ltd., Digana, Rajawella

${ }^{3}$ Department of Agribusiness Management, Faculty of Agricultural Sciences, Sabaragamuwa University of Sri Lanka.
} 
important as the present trend is towards the consumption of low fat food products. On the other hand cheese whey contains more than half of the total solids of the whole milk which is not recovered in the cheese production process (Lupando C.E. 1994 ). By utilizing whey, this amount can be recovered efficiently. Modern researches have found that whey protein has a potential for the improvement of health and prevention of diseases. (Bajaj R.K., Sangwan R.B. 2002 )

Developed countries produce different food products with whey. They produced whey cheese, whey butter, whey powder and different types of drinking items (Hauge, 2003) . Not every dairy producer has the capability to process whey into a usable product. The equipments required converting whey into food and animal feed products often cost more than companies can afford, and which cause companies will often rely on land spreading to dispose of the whey byproduct. So in developing countries, as Sri Lanka, cheese producers cannot engage in producing such kind of products without having necessary equipments and machineries.

Cheese made by traditional or modern methods inevitably produce large quantity of whey. It is difficult to divers whey disposal from cheese technology but the disposal of whey is becoming a major industrial, health problem and nutritional disadvantage. (Hague Z.U. 2003.)

So it should not be thrown away as waste but it should be used for stock and human consumption. But in the absence of economically viable technology, still whey is not utilized industrially in Digana MILCO plant and whey has been regarded as a waste product for approximately ten years. Therefore a cultured milk beverage is supposed to be produced using the cheddar cheese whey.
Objective of the study was to formation of the most suitable cultured milk beverage using cheddar cheese whey with the expected packaging material via sensory evaluation.

\section{MATERIALS AND METHODS}

This study was carried out at the milk processing plant of the Milk Industry of Lanka Company Limited (MILCO) Digana as a laboratory experiment during the period of two months.

In order to gain the quality assessed new products, the tests carried out with raw materials were fat determination of whey (Gerber method), determination of total solid percentage, estimation of solid non fat (SNF) content, estimation of moisture percentage and estimation of acidity. Sugar, Mango pulp and milk powder were added in order to increase the value of the final product.

It was determined the effect of mango pulp on the culture activity. Here $1 \mathrm{~L}$ of mango pulp was added into 10L of filtered whey and pasteurized $\left(80^{\circ} \mathrm{C}\right.$ for $\left.30 \mathrm{~min}\right)$. Then the mixture was cooled to $44^{\circ} \mathrm{C}$ and inoculated with $1.2 \mathrm{~g}$ DVS culture. Same time a control was performed. Then the time taken to reach the desirable acidity level $(0.4 \%)$ was measured and compared with the resulted increment of acidity level of whey without mango pulp.

\section{Determination of the effect of sugar strength on the culture activity}

The effect of sugar strength on the culture activity was determined. Here $6 \mathrm{~kg}$ of sugar was added into 10L of filtered whey and pasteurized $\left(80^{\circ} \mathrm{C}\right.$ for $\left.30 \mathrm{~min}\right)$. Then the mixture was cooled to $44^{\circ} \mathrm{C}$ and inoculated with $1.2 \mathrm{~g}$ DVS culture. 
Same time a control was performed. Then the time taken to reach the desirable acidity level $(0.4 \%)$ was measured and compared with the resulted increment of acidity level of whey.

\section{Determination of the effect of acidity/temperature combination on the casein of milk powder}

Milk casein tends to coagulate once both acidity and the temperature are increased (Vijayakumar,M.P.,2001).Whether the milk is coagulated during achieving the desired acidity was checked by the following process.

In the same time the same procedure was followed only with whey without adding milk powder. The time taken to reach the desired acidity level was measured to determine the effect of milk powder on the culture activity and compared with the increment of acidity level of whey without milk powder. Milk was checked for its coagulation till the acidity reaches $0.4 \%$.

\section{Determination of the appropriate production process}

According to the results of the above tests for the ingredients, the convenient process with available resources was found and it is given below.

Raw whey was removed from the cheese making process and it was filtered with a filtering cloth to remove curd particles of cheese making.Required amount of whey and mango pulp were measured to the milk can and it was pasteurized by keeping in a steam water bath. Then cooled to $44^{\circ} \mathrm{C}$ and the yoghurt culture (DVS) was added and incubated at $44^{\circ} \mathrm{C}$ in the incubation room till the acidity reaches $0.4 \%$. The sample preparation was done after the incubation period.

\section{Sample preparation}

There were three ingredients along with Whey. Two ingredients were changed (Sugar and milk powder) while whey and mango pulp were kept in a constant level respectively 1 liter and $100 \mathrm{ml}$ for each combination and nine samples were obtained as treatments according to the two factor factorial model. Milk powder and sugar were mixed with hot water. (similar to amount of sugar Eg:140g sugar and $20 \mathrm{~g}$ milk powder dissolved in $140 \mathrm{ml}$ of hot water) according to the following combinations. Each combination was pasteurized in $80^{\circ} \mathrm{C}$ for 30 minutes and both these pasteurized solutions (Whey/mango pulp and Milk powder/Sugar/Water) were cooled to $25^{\circ} \mathrm{C}$ and mixed together. 


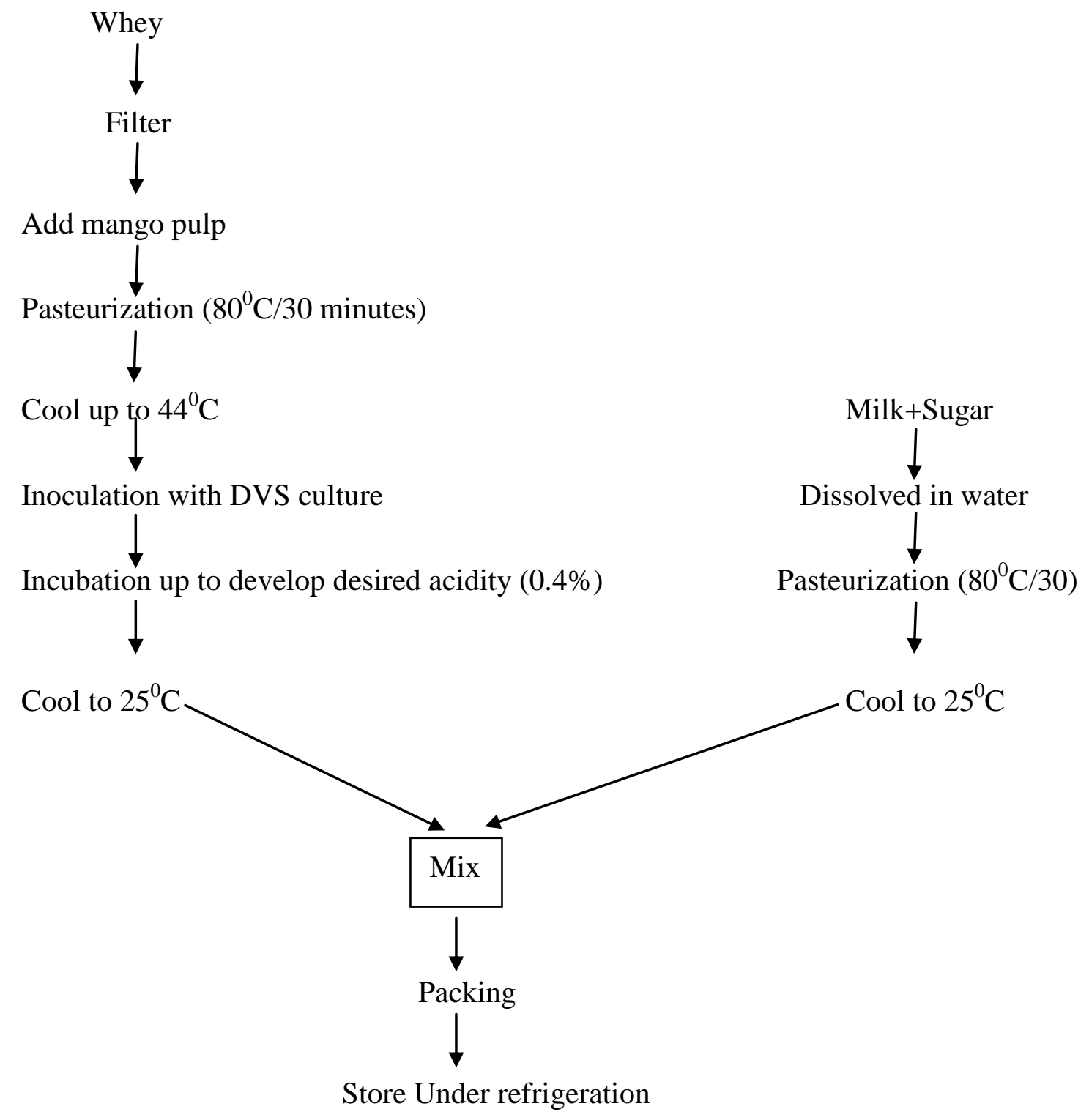

Figure 01: Flow Diagram of whey beverage processing

Table 01: Levels of ingredients for sample preparation

\begin{tabular}{llll}
\hline \multicolumn{1}{c}{ Ingredient } & \multicolumn{1}{c}{ Level 1 } & \multicolumn{1}{c}{ Level 2 } & Level 3 \\
& & & \\
\hline Sugar $(\mathrm{a})$ & $\mathrm{a}_{1=140 \mathrm{~g}}$ & $\mathrm{a}_{2}=160 \mathrm{~g}$ & $\mathrm{a}_{3}=180 \mathrm{~g}$ \\
Milk powder $(\mathrm{b})$ & $\mathrm{b}_{1=20 \mathrm{~g}}$ & $\mathrm{~b}_{2=40 \mathrm{~g}}$ & $\mathrm{~b}_{3}=60 \mathrm{~g}$ \\
\hline
\end{tabular}


Table 02: Mixing combination of milk powder and sugar with hot water

\begin{tabular}{llll}
\hline & \multicolumn{3}{c}{ Milk powder } \\
& Level $\mathrm{a}_{1}$ & Level $\mathrm{a}_{2}$ & Level $\mathrm{a}_{3}$ \\
& & & \\
\hline Level $\mathrm{b}_{1}$ & $\mathrm{a}_{1} \mathrm{~b}_{1}$ & $\mathrm{a}_{2} \mathrm{~b}_{1}$ & $\mathrm{a}_{3} \mathrm{~b}_{1}$ \\
Level $\mathrm{b}_{2}$ & $\mathrm{a}_{1} \mathrm{~b}_{2}$ & $\mathrm{a}_{2} \mathrm{~b}_{2}$ & $\mathrm{a}_{3} \mathrm{~b}_{2}$ \\
Level $\mathrm{b}_{3}$ & $\mathrm{a}_{1} \mathrm{~b}_{3}$ & $\mathrm{a}_{2} \mathrm{~b}_{3}$ & $\mathrm{a}_{3} \mathrm{~b}_{3}$ \\
\hline
\end{tabular}

Table 03: Final mixing of ingredients

\begin{tabular}{ll}
\hline & $\begin{array}{c}\text { Combination } \\
\text { (Milk Powder+Sugar) }\end{array}$ \\
\hline $\mathrm{a}_{1} \mathrm{~b}_{1}$ & \multicolumn{1}{c}{ Whey(1L)/Mango Pulp (100ml) } \\
$\mathrm{a}_{1} \mathrm{~b}_{2}$ & $\mathrm{a}_{1} \mathrm{~b}_{1}+$ Whey/Mango Pulp \\
$\mathrm{a}_{1} \mathrm{~b}_{3}$ & $\mathrm{a}_{1} \mathrm{~b}_{2}+$ Whey/Mango Pulp \\
$\mathrm{a}_{2} \mathrm{~b}_{1}$ & $\mathrm{a}_{1} \mathrm{~b}_{3}+$ Whey/Mango Pulp \\
$\mathrm{a}_{2} \mathrm{~b}_{2}$ & $\mathrm{a}_{2} \mathrm{~b}_{1}+$ Whey/Mango Pulp \\
$\mathrm{a}_{2} \mathrm{~b}_{3}$ & $\mathrm{a}_{2} \mathrm{~b}_{2}+$ Whey/Mango Pulp \\
$\mathrm{a}_{3} \mathrm{~b}_{1}$ & $\mathrm{a}_{2} \mathrm{~b}_{3}+$ Whey/Mango Pulp \\
$\mathrm{a}_{3} \mathrm{~b}_{2}$ & $\mathrm{a}_{3} \mathrm{~b}_{1}+$ Whey/Mango Pulp \\
$\mathrm{a}_{3} \mathrm{~b}_{3}$ & $\mathrm{a}_{3} \mathrm{~b}_{2}+$ Whey/Mango Pulp \\
\hline
\end{tabular}

$\mathrm{N}: \mathrm{B}$ : In each level whey and mango pulp mix was kept constant at $(1 \mathrm{~L}+100 \mathrm{ml})$ and other ingredients were changed according to the combination of the above table. These samples were cooled under refrigeration conditions.

A sensory evaluation test was done to get inspiration about the best ingredient combination to be in the final product. A well prepared structured questionnaire was given to 20 panelists. The panelists were selected from quality control division, production division and colleagues of trainees.

Panelists were asked to evaluate coded samples for degree of liking on a five hedonic scale. The hedonic scale comprises from very good to very poor. Parameters considered in the sensory evaluation were flavor, colour, smell, sourness and overall acceptability.
Sensory data analysis was carried out using the Freidman test of the Minitab 15 software. Freidman test is a nonparametric analysis of a randomized block experiment, and thus provides an alternative to the two way analysis of variance.

\section{Detection of chemical qualities of whey beverage}

The best sensory scored ingredient combination was re prepared and packed using the packing machine. They were evaluated for the chemical and microbiological qualities. Following chemical qualities were considered.

- Determination of fat percentage.

- Determination of total solids percentage.

- Determination of Solid non fat percentage.

- Determination of moisture level percentage. 
- Determination of acidity level.

In the detection of chemical qualities of the whey beverage, the same procedure used in the raw whey was practiced.

\section{Detection of Microbiological factors}

Following microbiological qualities were considered in both whey beverage and empty packets which whey beverage is stored.

- Testing for Coliform and E.Coli

- Testing for the yeast and moulds Also Total Colony Count was tested only for the empty packets.

\section{Shelf life evaluation}

Shelf life evaluation was carried out for the highest sensory scored beverage sample. They were stored in the standard packing materials at refrigeration conditions $\left(6^{\circ} \mathrm{C}\right)$.

Following qualities were observed in order to find out the shelf life in required days under the supervision of the Head of the quality control division of the Digana Milk factory.

1. Organoleptic qualities (Daily)

- Taste

- appearance

- Smell

- Texture

2. Chemical qualities (Daily)

- Acidity

3. Microbial qualities (Once in 5 days)

- Yeast and Moulds

\section{RESULTS AND DISCUSSION}

\section{Composition of whey}

Following results were obtained for the different constituents in the cheddar cheese whey of Digana MILCO factory.According to the results whey has a low fat percentage and also it contains more than half of the total solids of whole milk. In compared with raw milk, whey has a higher moisture percentage.

\section{Titrable Acidity}

The result of the titration for the average acidity was $0.13 \%$ and the $\mathrm{pH}$ of the whey was found to be 6.76 at the temperature of $28.2^{\circ} \mathrm{C}$. It is more or less similar to the acidity of good quality raw milk. But Under this acidity condition the unacceptable taste of the cheddar cheese whey is prominent.

Determination of the effect of mango pulp on the culture activity

Initial Acidity level of whey was $0.13 \%$,initial Acidity level of mango pulp was $0.81 \%$ and Acidity level of whey after adding mango pulp was $0.175 \%$.

Time of beginning incubation was 1.45 pm. 
Table 04: Composition of Cheddar cheese whey

\begin{tabular}{ll}
\hline Content & Percentage \\
\hline Fat & $0.3 \%$ \\
Total Solid & $6.75 \%$ \\
Solid non fat & $6.45 \%$ \\
Moisture & $93.25 \%$ \\
\hline
\end{tabular}

Table 05: Acidity increment of whey with and without Mango Pulp

\begin{tabular}{llc}
\hline Time & \multicolumn{2}{c}{ Acidity Increment of whey } \\
& Without Mango pulp & With Mango pulp \\
\hline $2.15 \mathrm{pm}$ & $0.130 \%$ & $0.175 \%$ \\
$3.45 \mathrm{pm}$ & $0.130 \%$ & $0.175 \%$ \\
$5.15 \mathrm{pm}$ & $0.150 \%$ & $0.185 \%$ \\
$6.00 \mathrm{pm}$ & $0.205 \%$ & $0.255 \%$ \\
$6.30 \mathrm{pm}$ & $0.270 \%$ & $0.32 \%$ \\
$7.15 \mathrm{pm}$ & $0.375 \%$ & $0.40 \%$ \\
$7.40 \mathrm{pm}$ & $0.405 \%$ & - \\
\hline
\end{tabular}

\section{Acidity Increment of Whey with \& without Mango pulp}

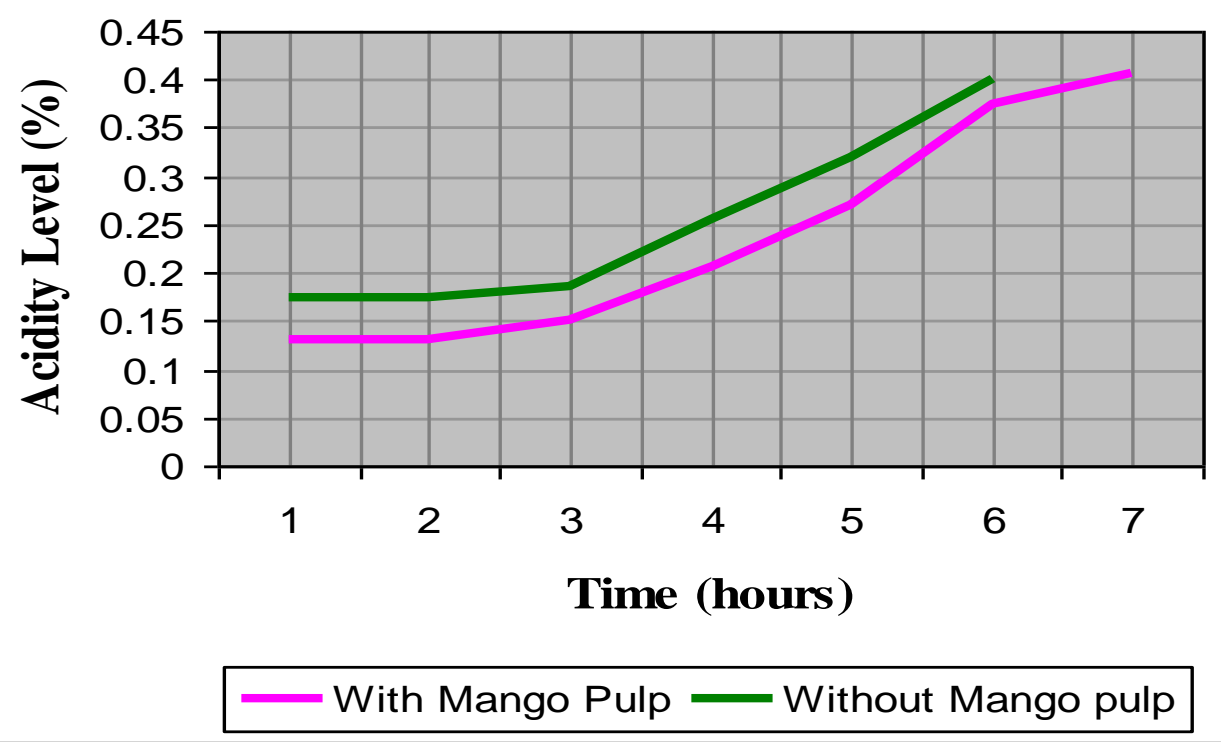

Figure 02: Acidity increment of whey with and without Mango pulp 
According to these results, Mango pulp helps to increase the initial acidity level of cheese whey. It causes the faster achieving of desired acidity other than only whey is incubated.
Determination of the Effect of sugar strength on culture activity

Initial Acidity level of whey- $0.13 \%$

Acidity of whey after adding sugar was

$0.13 \%$. Incubation was started at $1.00 \mathrm{pm}$

Table 06: Acidity Increment of whey with and without sugar

Time

Acidity increment of whey

\begin{tabular}{lcl} 
& Without sugar & With sugar \\
\hline $2.00 \mathrm{pm}$ & $0.13 \%$ & $0.13 \%$ \\
$3.00 \mathrm{pm}$ & $0.13 \%$ & $0.13 \%$ \\
$4.05 \mathrm{pm}$ & $0.14 \%$ & $0.13 \%$ \\
$4.40 \mathrm{pm}$ & $0.175 \%$ & $0.15 \%$ \\
$5.40 \mathrm{pm}$ & $0.285 \%$ & $0.185 \%$ \\
$6.10 \mathrm{pm}$ & $0.375 \%$ & $0.24 \%$ \\
$7.00 \mathrm{pm}$ & $0.415 \%$ & $0.295 \%$ \\
$7.20 \mathrm{pm}$ & - & $0.345 \%$ \\
$8.00 \mathrm{pm}$ & - & $0.39 \%$ \\
\hline
\end{tabular}

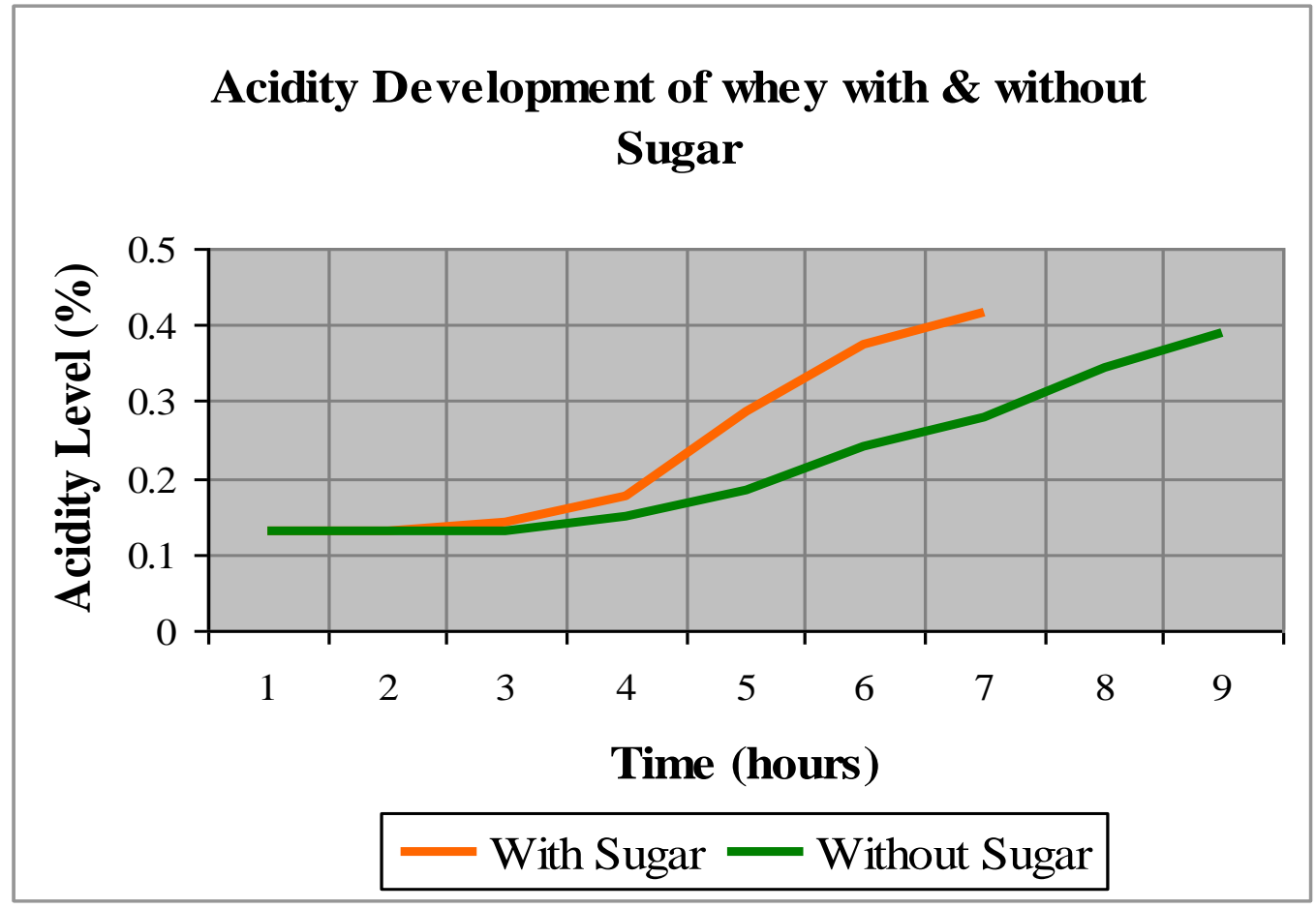

Figure 03: Acidity increment of whey with and without Sugar 
According to this graph, it has taken a longer time to reach the desired acidity level when incubated with sugar and it took only lesser time to reach the same acidity level under absence of sugar. It ensures that there is a significant effect of sugar $(160 \mathrm{~g} / 1 \mathrm{~L}$ of whey) strength on the culture activity. It delays the incubation period which is taken to achieve the desired acidity.
Determination of the Effect of acidity /heat combination on the casein of milk powder

Initial Acidity level of whey was $0.13 \%$.Acidity level of whey after adding milk powder was $0.13 \%$.Beginning Incubation time was $1.15 \mathrm{pm}$

Table 07: Effect of acidity on curdling

Time

Acidity \& Curdling

\begin{tabular}{lll} 
& Acidity & Curdling \\
\hline $2.15 \mathrm{pm}$ & $0.13 \%$ & No \\
$3.45 \mathrm{pm}$ & $0.15 \%$ & No \\
$4.15 \mathrm{pm}$ & $0.2 \%$ & No \\
$4.45 \mathrm{pm}$ & $0.24 \%$ & No \\
$5.30 \mathrm{pm}$ & $0.36 \%$ & Yes \\
$5.50 \mathrm{pm}$ & $0.405 \%$ & Yes \\
\hline
\end{tabular}

According to these observations, when acidity level reaches $0.36 \%$ milk tends to curdling. So it is clear that incubation cannot be done after adding full cream milk powder, because it gives poor organoleptic qualities and poor sensory qualities.

\section{Sensory evaluation of whey beverage for} taste
The panelists have given their favour for different characteristics on a

hedonic scale. According to the results of the Friedman test for taste, The $\mathrm{P}$ values both adjusted for ties and unadjusted for ties were lower than $\alpha$ value (0.05). Therefore null hypothesis $\left(\mathrm{H}_{0}\right)$ is rejected and hypothesis $\left(\mathrm{H}_{1}\right)$ is accepted.

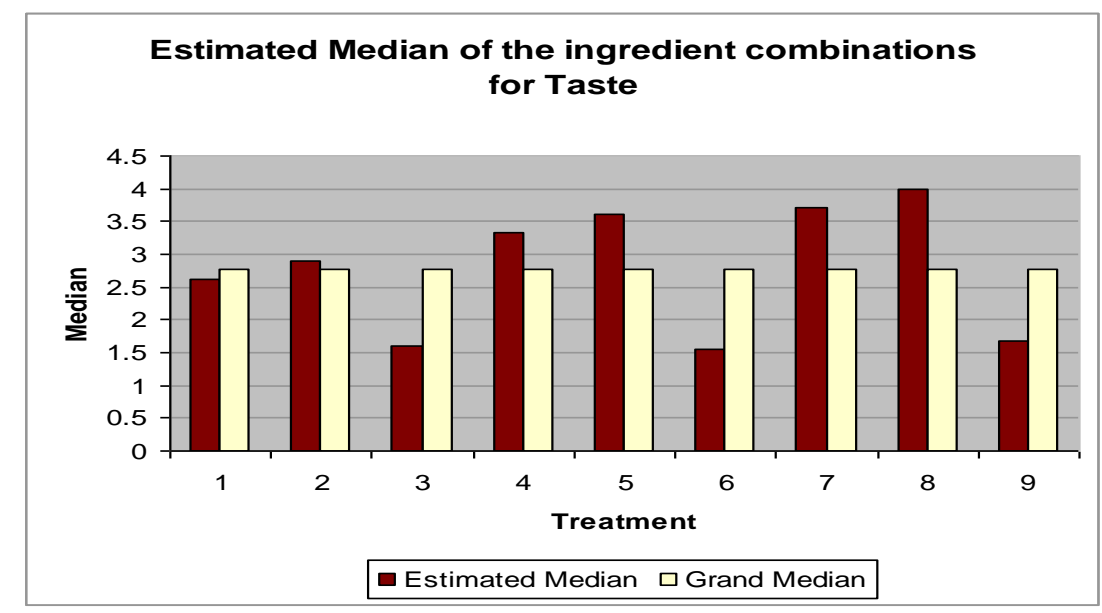

Figure 04: Sensory evaluation of whey beverage for taste 


\section{According to the Friedman test,}

Estimated median $=$ Grand median + treatment effect

Grand median of the Friedman test for taste was 2.778 and the treatment 8 had the highest treatment effect (Estimated median 4.000). Therefore the results prove that the treatment 8 is the highest sensory scored ingredient combination for taste. According to the estimated median, the other treatments with higher sensory scores were respectively treatment 7,5 , and 4.
Sensory evaluation of whey beverage for colour

According to the results of the Friedman test for colour, The $\mathrm{P}$ values both adjusted for ties and unadjusted for ties were lower than $\alpha$ value (0.05). Therefore $\mathrm{H}_{0}$ is rejected and $\mathrm{H}_{1}$ is accepted. It means changing the combinations of sugar and milk powder has a significant effect on colour. The grand median and the estimated medians of the different treatments for colour are given in the figure 4.4 .

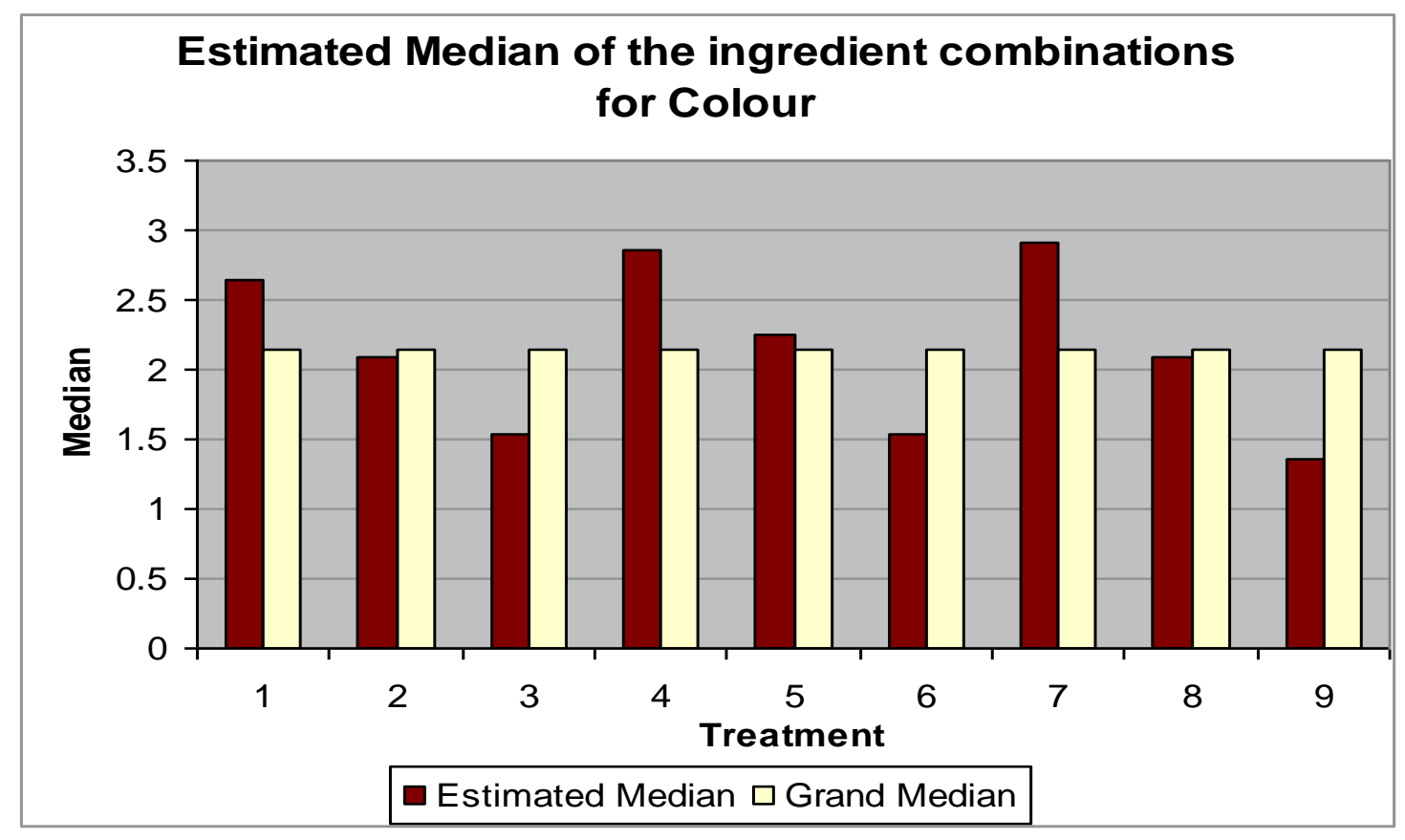

\section{Figure 05: Sensory evaluation of whey beverage for Colour}

Grand median of the Friedman test for colour was 2.1389 and the treatment 7 had the highest treatment effect (Estimated median 2.9167). Therefore it is apparent that the treatment 7 is the highest sensory scored ingredient combination for taste. According to the estimated median, the other treatments with higher sensory scores were respectively treatment 4,1 , and 5.
Sensory evaluation of whey beverage for sourness

According to the results of the Friedman test for sourness, The $\mathrm{P}$ values both adjusted for ties and unadjusted for ties were lower than $\alpha$ value (0.05). Accordingly null hypothesis $\left(\mathrm{H}_{0}\right)$ is rejected and the alternate hypothesis $\left(\mathrm{H}_{1}\right)$ is accepted. It emphasizes that changing the combinations of sugar and milk 
powder has a significant effect on the sourness.

Grand median of the Friedman test for sourness was 2.8333 and the treatment 8 had the highest treatment effect (Estimated median 3.3889). As a result, it is apparent that the treatment 8 is the highest sensory scored ingredient combination for sourness. In proportion to the estimated median, the other treatments with higher sensory scores were respectively treatment 7, 5, 9 and 4. Grand median and the estimated medians of the different treatments for sourness are given in figure 4.5 .

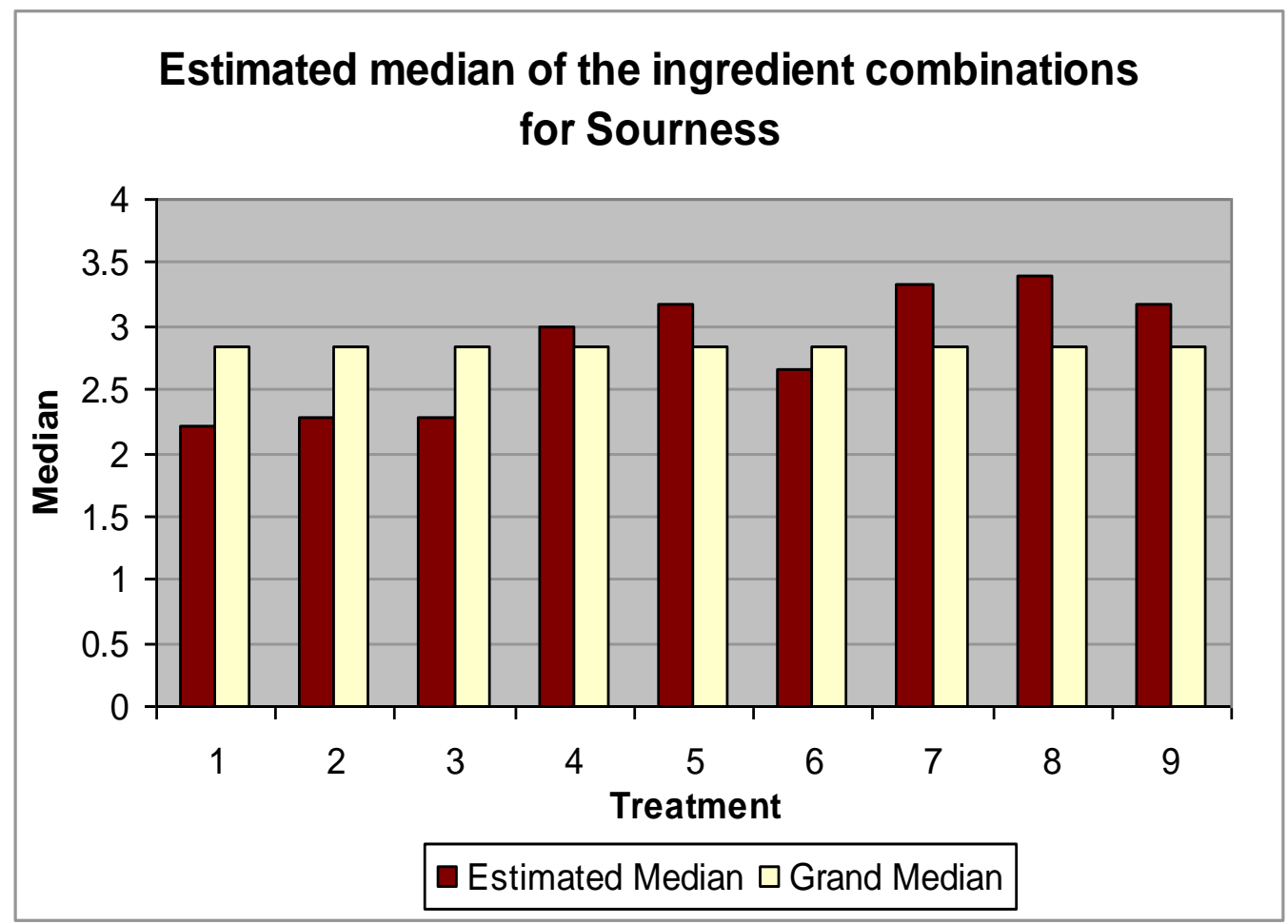

Figure 06 : evaluation of whey beverage for Sourness

Sensory evaluation of whey beverage for viscosity

According to the results of the Friedman test for viscosity, the test statistic, $\mathrm{S}$ has a $\mathrm{P}$ value of 0.694 adjusted for ties and 0.846 unadjusted for ties. For levels of 0.05 or 0.10 , there is insufficient evidence to reject the null hypothesis $\left(\mathrm{H}_{0}\right)$, because the $\mathrm{P}$ value is greater than $\alpha$ level. Therefore it is obvious that none of the treatments have an effect on the viscosity.
Sensory evaluation of whey beverage for overall acceptability

According to the results of the Friedman test for overall acceptability, The $\mathrm{P}$ values both adjusted for ties and unadjusted for ties were lower than $\alpha$ value (0.05). Therefore $\mathrm{H}_{0}$ is rejected and $\mathrm{H}_{1}$ is accepted. It means changing the combinations of sugar and milk powder has a significant effect on overall acceptability. Grand median and the estimated medians of the different treatments for overall acceptability are 
given in figure 4.6.Grand median of the Friedman test for overall acceptability was 2.944 and the treatment 8 had the highest treatment effect (Estimated median 4.000). Therefore, it is clear that the treatment 8 is the highest sensory scored ingredient combination for overall acceptability. In relation to the estimated median, the other treatments with higher sensory scores were respectively treatment 7,4 , and5.

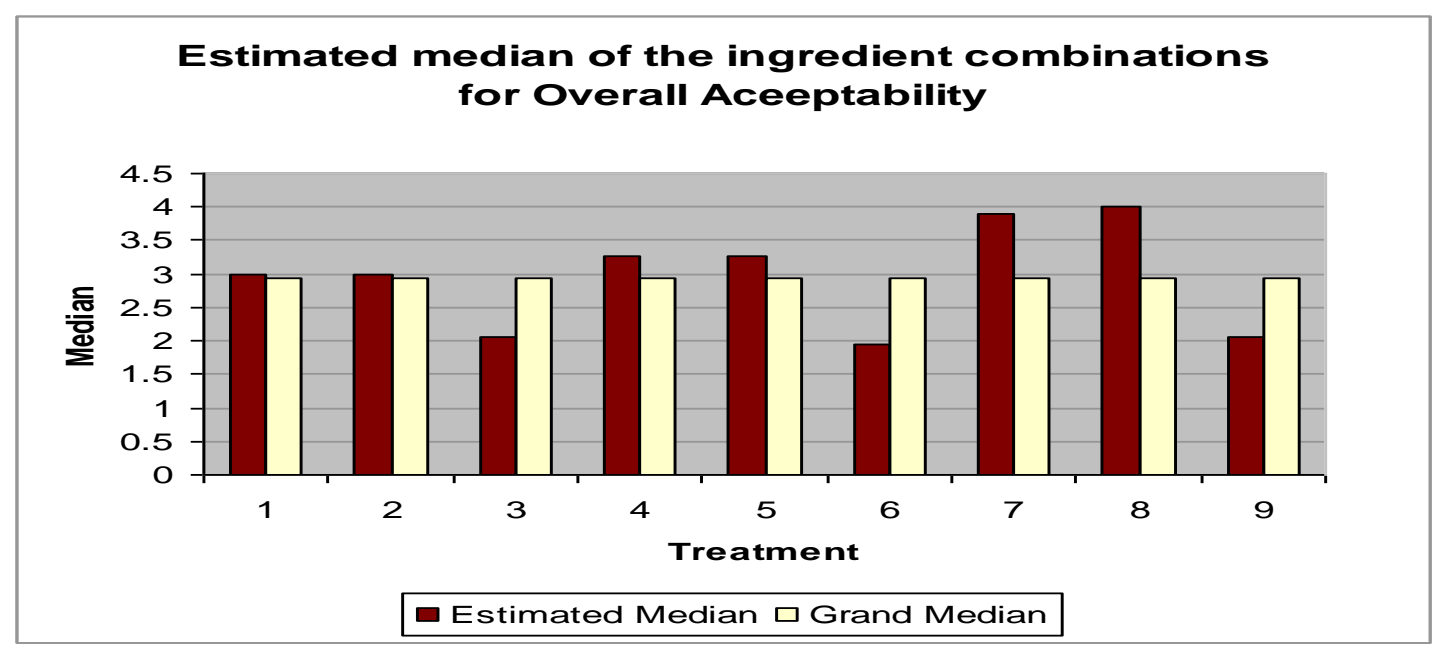

Figure: 07: Sensory evaluation of whey beverage for Overall acceptability

According to the results of the Friedman test for all the parameters, as a whole the most sensory scored treatment is treatment 8 and it is the highest sensory scored treatment for taste, sourness and overall acceptability except colour. In viscosity, all the treatments have been responded similarly for all the treatments and have a same estimated median value and a grand median value. Therefore none of the treatments have an effect on the viscosity

Table 08: Descriptive summary of the Freidman test for the $8^{\text {th }}$ treatment

\begin{tabular}{lcccc}
\hline \multicolumn{1}{c}{ Sensory Character } & probability & $\begin{array}{c}\text { Grand } \\
\text { median }\end{array}$ & $\begin{array}{c}\text { Estimated } \\
\text { median }\end{array}$ & $\begin{array}{c}\text { Treatment } \\
\text { effect }\end{array}$ \\
\hline Taste & $\mathrm{P}_{1}=0.000, \mathrm{P}_{2}=0.00$ & 2.7780 & 4.0000 & +1.2220 \\
Colour & $\mathrm{P}_{1}=0.000, \mathrm{P}_{2}=0.00$ & 2.1389 & 2.0833 & -0.0556 \\
Sourness & $\mathrm{P}_{1}=0.000, \mathrm{P}_{2}=0.00$ & 2.8833 & 3.3889 & +0.5056 \\
Viscosity & $\mathrm{P}_{1}=0.694, \mathrm{P}_{2}=0.846$ & 1.0000 & 1.0000 & - \\
Overall acceptability & $\mathrm{P}_{1}=0.000, \mathrm{P}_{2}=0.00$ & 2.9440 & 4.0000 & +1.0560 \\
\hline
\end{tabular}

P1 = Probability - Unadjusted for ties

P2 = Probability - Adjusted for ties 
As treatment 8 is the highest sensory scored one for three sensory characteristics out of five, it is obvious that the treatment 8 has the ingredient combination which is the most suitable for the preparation of the whey drink. It is consisted with $01 \mathrm{~L}$ of whey, $100 \mathrm{ml}$ of mango pulp, $180 \mathrm{~g}$ of sugar and $40 \mathrm{~g}$ of milk powder.
Detection of Chemical qualities of whey drink

After finding that the treatment 8 is the most sensory scored ingredient combination as a whole, the chemical composition of the treatment 8 was measured and the results were found to be as follows.

Table 09: Composition of highest sensory scored treatment

\begin{tabular}{ll}
\hline \multicolumn{1}{c}{ Composition } & Percentage \\
\hline Fat & $0.5 \%$ \\
Total Solids & $22.94 \%$ \\
Solid Non Fat & $22.44 \%$ \\
Moisture & $77.06 \%$ \\
\hline
\end{tabular}

According to the table 4.5 it is clear that the whey beverage has a low fat percentage, yet it is higher than the initial fat level of whey. When compared to the initial whey the total solid content of this treatment was much higher. In response to the changes of fat and total solid content, the level of SNF has been increased and the moisture level has been decreased than the initial level in raw whey.Preferably the titrable acidity level of the final product has been increased up to $0.405 \%$ due to the action of the starter culture.

\section{Detection of Microbiological qualities}

Microbiological qualities were checked for both final product (Treatment 8) and the empty packets which were used to store the product.

The microbiological qualities of whey beverages was as follows.
In testing for Coliform and E. Coli, results indicated that the sample of whey drink did not produce either acid or gas. Therefore, it was proved that there was no Coliform or E. Coli present.

In testing for Yeast and Moulds results indicated that the sample of whey drink did not have any Yeast and Moulds after 5 days. Therefore it was proved that there was no Yeast or mould present.

The microbiological qualities of the empty packets was as follows.

In testing for Coliform and E. Coli, results indicated that the sample neither produce acid nor gas after 2 days. Therefore, it is obvious that there were no Coliform or E.Coli present in the empty packets.

In testing for Yeast and Mould results indicated the sample was free of Yeast or 
Moulds after 5 days. Therefore, it is clear that there were no Yeast or Mould present in the empty packets.

In testing for Total Colony Count Results indicated that there was no any colony count after 2 days. Therefore, it is clear that there was no TCC in the empty packets.

\section{Shelf life evaluation}

Shelf life evaluation of the whey drink for organoleptic properties were as follows

Table 10: Shelf life evaluation of the whey drink for organoleptic properties

\begin{tabular}{llcccc}
\hline Day & & \multicolumn{4}{c}{ Quality } \\
& Flavour & Appearance & Smell & viscosity & Sourness \\
\hline 1 & Good & Good & Good & Good & Good \\
3 & Good & Good & Good & Good & Good \\
4 & Good & Good & Good & Good & Good \\
5 & Good & Good & Good & Good & Good \\
6 & Good & Good & Good & Good & Good \\
7 & Good & Good & Good & Good & Good \\
8 & Good & Good & Good & Good & Good \\
10 & Good & Good & Good & Good & Good \\
11 & Good & Good & Good & Good & Good \\
12 & Poor & Average & Good & Thickness high & Poor \\
13 & Poor & Clot form & Average & Thickness high & High \\
\hline
\end{tabular}

According to the table 4.7, flavour and sourness has become poor from the day 12. That is because the flavor depends on the sourness. Appearance was average. In the viscosity of the whey beverage was increased from the day 12. However in the day 13 an unpleasant clot forming could be visible. Sourness was high. Considering all these factors, according to the sensory qualities of the organoleptic properties we can recommend 11 days of shelf life for the whey beverage.

Shelf life evaluation of the whey drink for chemical qualities were as follows titrable acidity levels of the whey beverage in subsequent days are given in table 4.8. 
Table 11 : Shelf life evaluation results of the whey drink for chemical qualities

\begin{tabular}{ll}
\hline Date & Acidity \\
\hline 1 & $0.415 \%$ \\
3 & $0.42 \%$ \\
4 & $0.425 \%$ \\
5 & $0.425 \%$ \\
6 & $0.44 \%$ \\
7 & $0.45 \%$ \\
8 & $0.48 \%$ \\
10 & $0.56 \%$ \\
11 & $0.635 \%$ \\
12 & $0.705 \%$ \\
13 & $0.78 \%$ \\
\hline
\end{tabular}

Results of the shelf life evaluation for chemical qualities demonstrate that there is an increment of the acidity with the time. With the acidity development sourness was also increased. So according to the chemical qualities, shelf life is limited to 12 days.

Shelf life evaluation of the whey drink for microbiological qualities were as follows

Table 12: Shelf life evaluation results of the whey drink for microbiological qualities

\begin{tabular}{ccc}
\hline Date & Yeast & Molds \\
& & \\
\hline 1 & Nil & Nil \\
3 & Nil & Nil \\
4 & Nil & Nil \\
5 & Nil & 2 \\
6 & Nil & 2 \\
7 & Nil & 2 \\
8 & Nil & 2 \\
10 & Nil & 4 \\
12 & 1 & 6 \\
13 & 2 & 8 \\
\hline
\end{tabular}

According to the microbiological qualities of the shelf life evaluation (Table 4.9.) moulds were observed from the $5^{\text {th }}$ day and the yeast was observed on the day 12 . However as the total of the yeast and mold in the $13^{\text {th }}$ day were only equal to 10 (normally the standard level of yeast and molds for $10 \mathrm{mls}$ of the cultured product is yeast 10 and mold 10 colonies respectively) and accordingly the shelf life evaluation for microbiological qualities could be carried out furthermore. Though microbiological conditions are better even after 11 days, the shelf life of the product had to be determined only for 11 days by considering organoleptic qualities. 


\section{CONCLUSIONS}

According to the results, whey can be effectively utilized for the production of a cultured milk beverage using the cheddar cheese whey for the human consumption. In relation to the results of the sensory evaluation, the most preferred ingredient combination for the whey beverage is 1 liter of whey, $100 \mathrm{ml}$ of Mango pulp , $40 \mathrm{~g}$ of Milk powder and 180g of Sugar.

When considering the composition of the whey beverage, the fat level is $0.5 \%$. So, this can be introduced to the market as a non fat product.

The resulted shelf life of the shelf life evaluation of the whey beverage is 11 days. The major barrier to achieve the highest shelf life (Cultured products should have at least 15 days of shelf life) is the changing of organoleptic qualities. The Organoleptic qualities are hand in hand with the chemical composition and microbiological qualities of the product. Therefore, these all factors should be considered together to improve the shelf life of the product.

\section{References}

Bajaj R.K. and R.B. Sangwan (2002). Health Enhancing Potentials of Whey proteins-A

Review. Dairy Chemistry Division, National Dairy Research Institute, Karnal 132001, Haryana. pp 253-258.

Hague Z.U. (2003). Cheddar Whey Processing and Source. International Journal of Food Science and Technology. 38: pp 463-465.

Lawless H.T. and H. Hymann (1999). Sensory Evaluation of Food. Aspen Publishers Inc., Gaithersburg, Maryland. pp 446-449.

Lupando C.E. (1994). Effect of heat treatment in very acidic conditions on Whey protein isolate properties. Journal of Dairy Science. 77: pp 2191-2198

Mathur M.P., D.D.Roy and P.Dinakar (1999). Tex Book of Dairy Chemistry. Directorate of Information and Publications of Agriculture, Indian Council of Agricultural Research, Krisiti Anusandhan Bhavan, Pusa, New Delhi 110012. pp 384-394.

Donnell C.D.(1992). Secrets to successful sensory evaluation - Food Development: Formulation Challenge. Prepared Food. Gale Group, 27500, Drake Road, Farmington Hills. 10 August 2007. http://findarticles.com/p/articles

Robinson R.K. (2002). Dairy Microbiology Hand Book. $3^{\text {rd }}$ Edition. A. John Willey and Sons Inc. Publication. pp 17-68.

Sensory Evaluation. (2003). British Nutrition Foundation. 04 August 2007. http://www.nutrition.org.uk

Wijayakumar B. and R.B. Sangwan (2001). Heat Coagulated Whey Protein Hydrolysates, Solubility and Emulsifying Properties. Dairy Chemistry Division, National Dairy Research Institute, Karnal 132001. 49: pp 278-279.

Wang M.P., R. Jenness, M. Keeney and E. H. Marth (1998). Fundamentals of Dairy Chemistry. $3^{\text {rd }}$ Edition. CBS Publishers and Distributors, 11, Darya Ganj, New Delhi, 110002, India. pp 676-677.

Widcome R.(1978). The Cheese Book. Seacaucus: Chartwell Books, 07 July 2007 http://www.godecookery.com/how2cook/cheesnet.htm 